\title{
The impact of environmental factors on distribution of Scops Owl Otus scops IN THE WIDER area of KRAS (SW SlOVENIA)
}

\section{Vpliv okoljskih dejavnikov na razširjenost velikega skovika Otus scops na širšem območju Krasa (JZ Slovenija)}

\author{
Tina ŠušMeLJ \\ Vrtnarija 12a, SI-1360 Vrhnika, Slovenia, e-mail: setina@gmail.com
}

The aim of the study was to determine the key environmental factors affecting Scops Owl Otus scops occurrence in the wider Kras plateau area (SW Slovenia, $665 \mathrm{~km}^{2}$ ). Scops Owl was systematically censused in 2006 (180 calling males) and in 2008 (167 calling males). Males were distributed either solitarily or clumped in groups, mostly situated in villages and its surroundings, indicating the species' synanthropic character. Crude densities were $0.3 \mathrm{males} / \mathrm{km}^{2}$ in 2006 and 2008, respectively, while ecological densities were $1.0 \mathrm{males} / \mathrm{km}^{2}$ in 2006 and 0.9 males $/ \mathrm{km}^{2}$ in 2008. Population distribution remained roughly the same in both years, with the highest densities in the western and central parts of the Kras plateau, on Kraški rob and on Podgorski kras plateau. Habitat selection was analyzed at three spatial scales (regional, settlement and territory scales), based on spatial data layers (22 environmental variables), using Chi-square goodnessof-fit test and logistic regression. Results revealed that at the regional scale, Scops Owl preferably selected open habitats (extensively managed orchards, built-up areas, vineyards, permanent grasslands) and avoided dense forest and agricultural land with forest trees. As far as settlements were concerned, Scops Owl was more prone to select those that were more distant from the highway, with better preserved traditional agricultural landscape (with more hedgerows) and with higher average annual air temperature. In territory selection, Scops Owl occurrence was associated with longer distance from the highway, larger number of old buildings and higher landscape mosaics. The species seems to be threatened by traffic noise, habitat loss through abandonment and intensification of land and, potentially, by lack of breeding niches within settlements. Conservation measures should include the preservation of mosaic farmland, promotion of extensive agricultural practices, prevention of scrub and forest expansion, and maintenance of breeding niches (old trees, cavities in buildings).

Key words: Scops Owl, Otus scops, environmental variables, distribution, habitat selection, GIS, logistic regression, Kras

Ključne besede: veliki skovik, Otus scops, okoljski dejavniki, razširjenost, izbor habitata, GIS, logistična regresija, Kras

\section{Introduction}

The Scops Owl Otus scops is a small, insectivorous, nocturnal raptor, typical for open and semi-open grassland habitats, rich in insects (CrAMP I998). In Europe, it is considered depleted due to its large historical decline between 1970 and 1990 (BIrdLife
InTERnATIONAL 2004). Steep declines have been reported for countries in the northern breeding range, e.g. Switzerland (Arlettaz et al. I99I) and Austria (Samwald \& Samwald I992), and even for Mediterranean countries that hold the largest part of European population of this species, such as Spain, Croatia and Italy (SACCHI et al. I999, BirdLife 
T. ŠušmelJ: The impact of environmental factors on distribution of Scops Owl Otus scops in the wider area of Kras (SW Slovenia)

INTERNATIONAL 2004, MARTINEZ et al. 2007).

In Slovenia, Scops Owl has a status of endangered species (status E2 in the Slovenian Red list of threatened species, URADNI LIST RS 2002). It is a protected species (URADNI LIST RS 2004A) as well as a qualifying (triggering) species in the following three Slovene Special Protection Areas (SPA): Kras, Goričko, and Ljubljansko barje (URADNI LIST RS 2004C). The most recent estimate of the Slovene Scops Owl population is 600-1,000 pairs (DenaC et al. 2OIIA). The most important breeding areas are in SW Slovenia (Kras, Snežnik - Pivka and Slovenian Istria), in central Slovenia (Ljubljansko barje), and in eastern and NE Slovenia (Goričko, Kozjansko). In Kras, the population is currently estimated at 120-200 pairs, in Snežnik - Pivka at 40-50 pairs and in Slovenian Istria at 20-40 pairs (Denac et al. 20 i ia). At Ljubljansko barje, the population fluctuated greatly during the 1998-2010 period when ranging between 40-65 pairs (SenegaČnik i998, Denac 2000A \& 2003, Rubinič et al. 2004 \& 2008, Denac et al. 2010). In Goričko, the Scops Owl population was reduced by more than 70\% during the 1997-2011 period (ŚTUMBerger 2000, Rubinič et al. 2004, 2007 \& 2009, DenaC et al. 20ІІв) and was estimated at 100-160 pairs in the 2004-2009 period (Denac et al. 20 i ia). In the Kozjansko area, the population is estimated at 60-70 pairs (Denac et al. 20IIA). Several other localities scattered throughout the country jointly hold a few tens of breeding pairs (Polak 2000, Denac et al. 2OIIA).

Previous studies have suggested that the Scops Owl population in Europe is declining mainly because of changes in agricultural practices (Arlettaz et al. i 99i, SACCHi et al. i999, Sergio et al. 2009). At Ljubljansko barje, the intensification of farmland and urbanisation are estimated to be the two major threats to this species (Denac 2009), while in Goričko the intensification of farmland, especially through land consolidation, is probably the cause for the recent steep decline of Scops Owl population (Denac et al. 20 I IB). In the wider area of Kras, Scops Owl is still widespread in some areas, but an overall population decline was noted in the 2006-2010 period (RUBinič et al. 2006 \& 2008, Denac et al. 2010). Therefore, a better understanding of habitat requirements is needed for conservation purposes. Based on census data from 2006 and 2008, we studied: (1) abundance, spatial distribution and density of Scops Owl, and (2) habitat selection at three different spatial scales in the wider area of Kras. Habitat in our study means a space in which a species finds suitable living conditions (environmental characteristics) necessary for its survival and reproduction (TARMAN I992), whereas habitat selection indicates a hierarchical process of selecting a habitat at different spatial scales (HutTo I985).

\section{Study area}

The study area $\left(665 \mathrm{~km}^{2}\right.$, SW Slovenia) extends over the Kras (eng. Karst, it. Carso) plateau, Kraški rob, which is a cascade of limestone cliffs, Podgorski kras plateau, Matarsko podolje valley, mountainous Čičarija plateau with Mt Slavnik, Mt Vremščica and southern edge of the Vipava River Valley (Figure 1). We named the study area after the largest geographical unit - Kras. The study area has been almost entirely declared an Important Bird Area, IBA SI003 Kras (Polak 2000), an Ecologically Important Area (Uradni list RS 2004B), and a Special Protection Area, SPA SI5000023 Kras (URAdNi LIST RS 2004C).

The study area is a flat to hilly, predominantly limestone area (karst). The average altitude is 425 $\mathrm{m}$ a.s.l. (GURS 2006), with the highest mountains being Mt Slavnik (1,028 m a.s.l.) and Mt Vremščica (1,027 $\mathrm{m}$ a.s.l.). The climate is submediterranean, with average annual air temperature around $11{ }^{\circ} \mathrm{C}$ (ARSO 2007A) and average annual rainfall ranging from 1,100 to $2,000 \mathrm{~mm}$ (ARSO 2007B). The landscape is dominated by a large proportion of forests, extensively cultivated grasslands, small vineyards, numerous hedgerows, scattered trees and stonewalls. Settlements are small and regularly distributed over the study area, with buildings clustered in groups and often built of stone. Today, $61.0 \%$ of the study area consists of forests, $22.0 \%$ of permanent grasslands, $4.4 \%$ of agricultural land in early successional stages of forest, $4.0 \%$ of builtup areas, $3.4 \%$ of agricultural land with forest trees, $2.0 \%$ of trees and scrub, $1.6 \%$ of vineyards, and only $0.3 \%$ of extensively managed orchards (MKGP 2007). Farming land has been abandoned over vast areas, which are now undergoing natural succession to scrub land and forest (TrONTELJ 2000). Extensive habitats in the study area have been lost due to highway construction (BožIČ 2003). The most widespread are sheep breeding and winegrowing. Intensive farming is practiced only in southern part of the Vipava River Valley, where amelioration and land consolidation changed the landscape drastically in the 1980s. Hedgerows and individual trees were removed almost entirely, arable fields were enlarged, ditches were dug, and permanent grasslands were replaced by intensive crops (e.g. vineyards and intensive fruit plantations) (GABRIJELČIČ et al. I 996). 


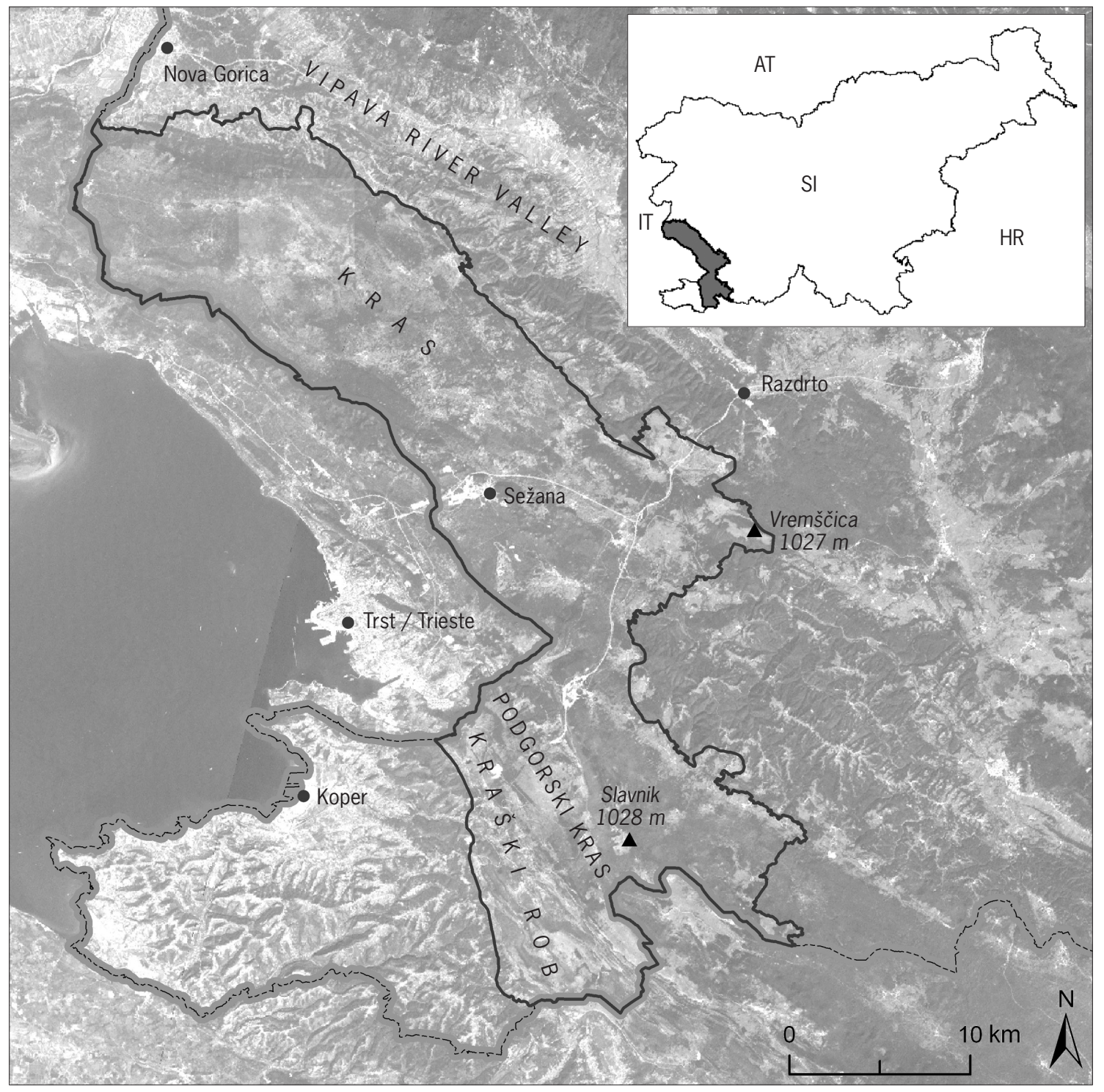

Figure 1: Location of the study area (SW Slovenia)

Slika 1: Lokacija območja raziskave (JZ Slovenija)

\section{Methods}

\subsection{Census method}

The Scops Owl census was carried out in 2006 and 2008 during their pre-incubation period in the beginning of May, in a clear weather. Each time it was performed during a single night (12/13 May 2006, 9/10 May 2008). At each census point we first listened to spontaneously calling Scops Owls for $2 \mathrm{~min}$, then broadcast a play-back of a male call for $2 \mathrm{~min}$ and waited for another 2 min for response (SAMWALD \& SAMWALD I992). The census was carried out mainly from points selected in the habitats that we considered potentially suitable for Scops Owl (settlements with their surroundings, larger cliffs and rocky hillsides, groups of old trees). Additionally, we also checked for Scops Owl in less suitable habitats (dense forest, areas with higher altitude). A priori suitable habitat was estimated on the basis of literature (GaLEOTti \& Gariboldi i 994, Keller \& Parrag i996, Benussi et al. I997, Štumberger 2000, Denac 2000A, 2003 \& 
T. ŠušmeLJ: The impact of environmental factors on distribution of Scops Owl Otus scops in the wider area of Kras (SW Slovenia)

2009, Marchesi \& Sergio 2005, Martinez et al. 2007. Sergio et al. 2009). According to their size, settlements were censused at one to three census points. Distance between census points was at least $500 \mathrm{~m}$. Altogether, we selected 351 census points in 2006, while in 2008 we visited additional 55 census points in less suitable habitat beside those from 2006 (for details see Šušmelj 20I2). The described census method was standardized for monitoring Scops Owl in Slovenia to enable comparison of data between different areas (Rubinič 2005).

\subsection{Selection of scales and habitat variables}

We entered 406 census points and 347 male locations (180 recorded in 2006 and 167 in 2008) into the Geographic Information System (ESRI 2005) using digital cartography on a scale of $1: 25,000$. Only males were entered as very few females were recorded duetting with males. Into GIS, the publicly available data layers were also entered, and layers of environmental variables were prepared on their basis.

For the habitat selection study, we selected three scales, which we adapted to the aims of our research.

At the regional scale, we aimed to asses the effect of land-use on spatial distribution of Scops Owl, since landscape has been found to affect patterns of abundance and distribution of birds (SEOANe et al. 2004). We compared the occupied land-use types (number of locations of males in each land-use type) with the available land-use types (relative area of each type).

At the settlements scale, we aimed to find out why Scops Owl was not present in many settlements, although looking similar as the occupied ones. Therefore, we compared occupied with unoccupied settlements, which we described as circular plots with a radius of $500 \mathrm{~m}$ around the centres of settlements (villages or towns). Radius of $500 \mathrm{~m}$ was chosen to encompass the major part of open farmland surrounding the settlements and the majority of males, and at the same time to minimize overlapping of circles. Settlement was defined as occupied if it had at least two males recorded within the circle during both census years ( $n=63$ settlements) and as unoccupied if there was no male recorded within the circle in both years ( $n=66$ settlements). Settlements which had only one male recorded during both census years $(n=33$ settlements) were excluded from the analysis because they probably represent a sub-optimal habitat and cannot be reliably classified into one of the two groups (occupied, unoccupied).

At the territory scale, we wanted to determine the key environmental factors influencing territory selection. Therefore, we compared unoccupied with occupied census plots, which we described as circular plots with a radius of $200 \mathrm{~m}$ around the census points. Since a playback was broadcast, territorial males usually approached the observers and possibly changed their usual position. Moreover, the locations of calling males could have been inaccurately entered into the map by observers. Therefore, we decided to choose an occupied census plot as the best approximation of Scops Owl's territory (e.g. VRezec \& ToMe 2004). A radius of $200 \mathrm{~m}$ is in agreement with the territory size observed in other areas; $100 \mathrm{~m}$ in STREIT \& Kalotás (I99I), territory size of 0.6 ha in Galeotti \& Gariboldi (1994) that would give a radius of 44 $\mathrm{m}, 70 \mathrm{~m}$ in Keller \& Parrag (i996), and $183 \mathrm{~m}$ in Martinez et al. (2007). Census plot was defined as occupied if it had at least one male recorded within the circle in one of the two census years $(n=106$ census plots) and was defined as unoccupied if no male was recorded within the circle in both census years $(n=$ 185 census plots).

Habitat of Scops Owl was described by 22 environmental variables (Table 1) (for details see ŠUŠMELJ 20I2). Values of environmental variables were calculated using ArcGIS (ESRI 2005). All the independent variables are continuous, except for the discrete variable "predominant orientation".

\subsection{Statistical analyses}

Distribution pattern of Scops Owl was estimated by the Nearest Neighbour Index $R_{n}$ (Clark \& Evans I954) using ArcGIS (ESRI 2005). Values smaller or larger than 1 indicate clumped or uniform patterns, respectively. Crude densities and ecological densities were calculated (suitable habitat was determined in the analysis of habitat selection at the regional scale; $187 \mathrm{~km}^{2}$, Table 2). To present the density of Scops Owl calling males in a separate census year, a map of kernel density was created (WORTON I989).

In the habitat selection analysis at the regional scale, each location of a male was assigned to a particular land-use type. Males from both census years were aggregated into one data set because we assumed that only a small proportion of the same individuals returned to the same location during 2006-2008 (Galeotti \& Sacchi 200I) and therefore each site represents an independent (new) habitat selection process. Chi-square goodness-of-fit test was used to test the null hypothesis that Scops Owl uses each land-use type in proportion to its availability within the study area (Neu et al. 1974, Byers et al. 1984). 
Table 1: Environmental variables included in habitat selection analyses at each of the three scales $(\bullet=$ variable included)

Tabela 1: Okoljske spremenljivke, vključene v analizo izbora habitata na posameznem prostorskem nivoju $(\bullet=$ spremenljivka vključena v analizo).

Environmental variable/

Okoljska spremenljivka

$\begin{array}{ccc}\text { Regional } & \text { Settlements } & \text { Territory } \\ \text { scale/ } & \text { scale/ } & \text { scale/ } \\ \text { Pokrajinski } & \text { Nivo } & \text { Nivo } \\ \text { nivo } & \text { naselij } & \text { teritorija }\end{array}$

Land-use / Raba tal

Fields / Njive (\%) ${ }^{\mathrm{a}}$

Vineyards / Vinogradi (\%)

Extensively managed orchards / Ekstenzivni oz. travniški sadovnjaki (\%)a

Permanent grasslands / Trajni travniki $(\%)^{a}$

Agricultural land in early succesional stages of forest/

Kmetijska zemljišča v zaraščanju (\%)

Trees and scrub / Površine z drevesi in grmičevjem (\%)

Agricultural land with forest trees/

Kmetijska zemljišča, porasla z gozdnim drevjem $(\%)^{a}$

Built-up and similar areas / Pozidana in sorodna zemljišča (\%)

Forest edge (50 m wide) / Gozdni rob (50-metrski pas v gozd) $(\%)^{\mathrm{a}}$

Dense forest / Notranji gozd (\%)

Indicators of traditional farmland / Kazalci tradicionalne kmetijske krajine

Landscape mosaics (number of land-use polygons)/

Mozaičnost krajine (št. vseh poligonov rabe tal) ${ }^{a}$

Landscape heterogeneity (number of different land-use types)/

Heterogenost krajine (št. različnih vrst rabe tal) ${ }^{\mathrm{a}}$

Length of hedgerows / Dolžina mejic $(\mathrm{m})^{\mathrm{a}}$

Average size of arable fields / Povprečna velikost ornih površin $\left(\mathrm{m}^{2}\right)^{\mathrm{a}}$

\section{Physiography / Fizično-geografske značilnosti}

Average annual air temperature / Povprečna letna temperatura zraka $\left({ }^{\circ} \mathrm{C}\right)^{\mathrm{b}}$

Average annual precipitation / Povprečna letna količina padavin $(\mathrm{mm})^{\mathrm{c}}$

Altitude / Nadmorska višina $(\mathrm{m})^{\mathrm{d}}$

Slope / Naklon površja $\left({ }^{\circ}\right) \mathrm{d}$

* Predominant orientation / Prevladujoča ekspozicija ${ }^{\mathrm{d}}$

Nesting, foraging, roosting requirements / Zahteve za gnezdenje, prehranjevanje, počivanje

Number of old buildings (built before 1940) / Število starih stavb (zgrajenih pred 1940) ${ }^{\mathrm{e}}$

** Potentially suitable habitat / Potencialno ustrezni habitat $(\%)^{a}$

\section{Human disturbance / Antropogene motnje}

Distance from highway / Oddaljenost od avtoceste oz. hitre ceste $(\mathrm{m})^{\mathrm{f}}$

Data source / Vir podatkov: a - MKGP 2007, b - ARSO 2007A, c - ARSO 2007B, d - GURS 2006, e - GURS 2009, f - GURS 2005

* Orientation: north-, NE-, east-, SE-, south-, SW-, west- and NW-facing slopes / Ekspozicija: S, SV, V, JV, J, JZ, Z in SZ usmerjeno pobočje

** Variable includes following land-use types (with original codes, after MKGP 2007): vineyards (1211), permanent grasslands (1300), extensively managed orchards (1222), agricultural land with forest trees (1800), built-up and similar areas (3000), dry open land with special herb layer (5000) and open land with or without insignificant herb layer (6000) / Spremenljivka vključuje naslednje vrste rabe zemljišč (z originalnimi kodami, MKGP 2007): vinograd (1211), trajni travnik (1300), ekstenzivni oz. travniški sadovnjak (1222), kmetijsko zemljišče, poraslo z gozdnim drevjem (1800), pozidano in sorodno zemljišče (3000), suho, odprto zemljǐ̌če s posebnim rastlinskim pokrovom (5000) in odprto zemljišče brez ali z nepomembnim rastlinskim pokrovom (6000) 


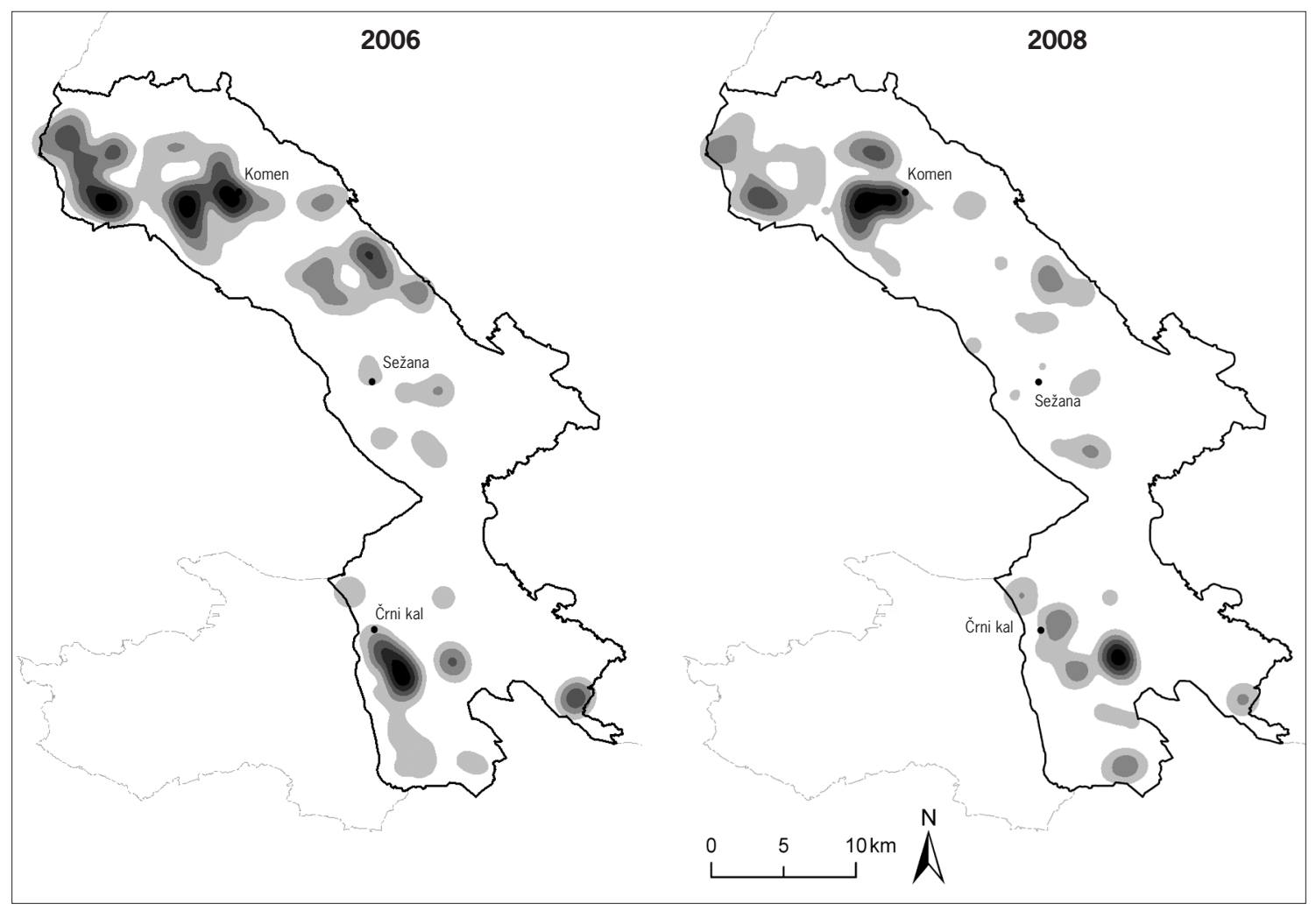

Figure 2: Local densities of Scops Owl Otus scops in the study area in 2006 and 2008 after kernel method, where darker areas delineate higher densities. Outside these areas, Scops Owl occurs as well, although in very small densities (only individual males).

Slika 2: Lokalne populacijske gostote velikega skovika Otus scops na območju raziskave v letu 2006 in 2008 po kernelski metodi, kjer temnejša območja ponazarjajo večjo gostoto. Veliki skovik se pojavlja tudi zunaj teh območij, vendar so tam gostote zelo majhne oz. gre le za posamične osebke.

To determine which land-use types are selected and which are avoided, selectivity index was calculated (the proportion of observed males within each landuse type divided by the proportion of total area of each land-use type) (Manly et al. 2002). An index value $>1$ indicates preference, while value $<1$ demonstrates avoidance of particular land-use type. Bonferroni adjusted confidence intervals were used to check whether preference or avoidance of particular land-use type is statistically significant (NeU et al. I974, Byers et al. 1984).

At the settlement and territory scale, the effects of environmental variables on occurrence of Scops Owl were analysed with binary logistic regression, the stepwise forward algorithm in the Windows software package SPSS 17.0. (SPSS 2008). The presence/ absence binary response was used as dependent variable and environmental variables as independent variables at each of the two scales (Table 1). At the territory scale, occupied census plots were weighted by the number of males recorded within the circle, but only data from one census year (the year with more males recorded) was included in order to avoid pseudoreplication of census points. Multicollinearity of independent variables was checked by the Spearman coefficient. If Spearman's correlation exceeded a threshold value of 0.5 , the variable with lower predictive power in univariate models (with lower R-square Nagelkerke, NAGELKERKE I99I) was omitted from the analysis (e.g. Graf 2005). Logistic regression assumes a linear relationship between the independent variables and the $\log$ odds (logit) of the dependent variable (GARSON 2009). To check this relationship, the method proposed by GARSON (2009) was applied. Thus, for each independent variable a new variable was created, which divides the existing variable into categories of equal intervals. Then a univariate logistic regression with newly categorised variable was run. 


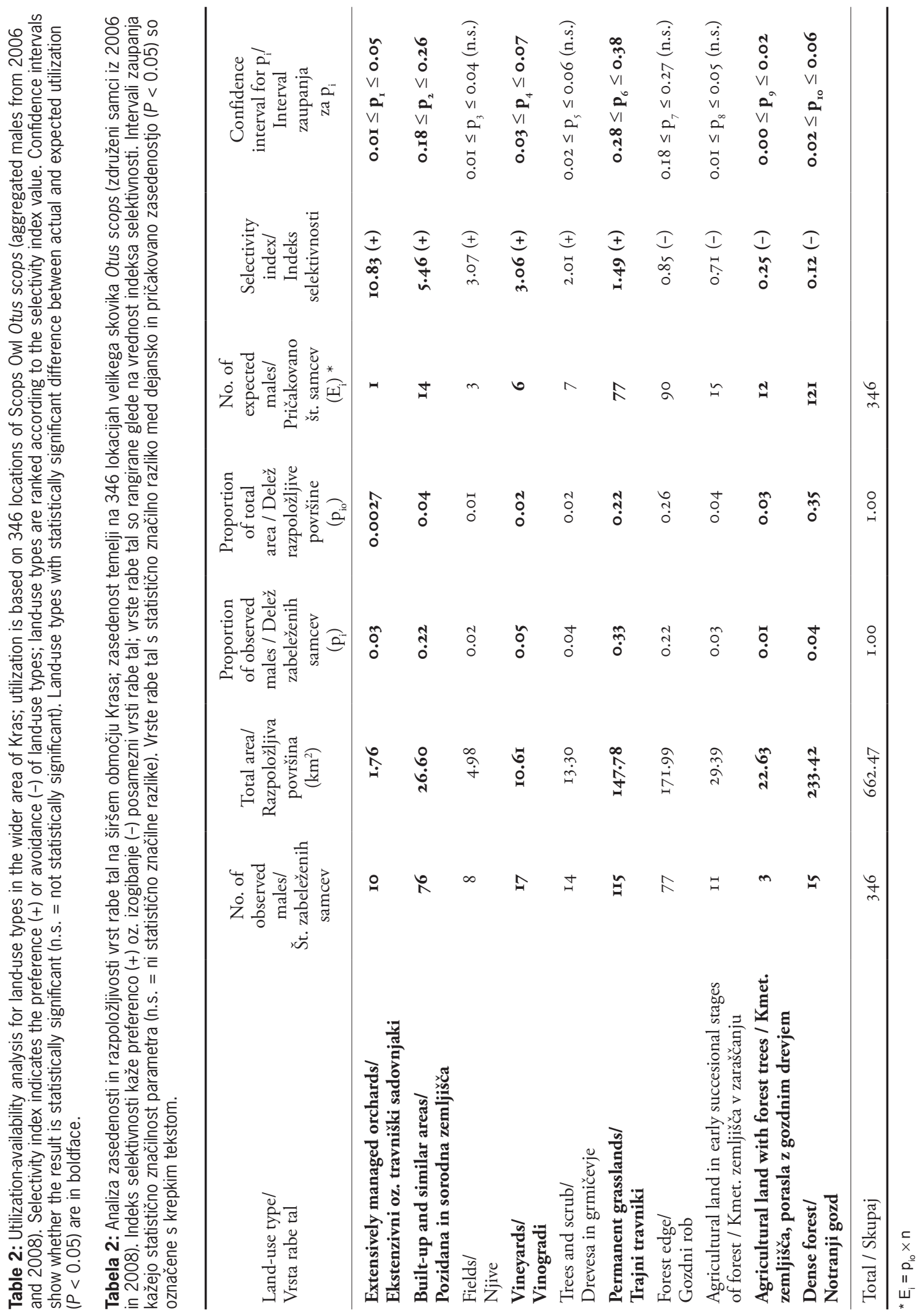


T. ŠušmeLJ: The impact of environmental factors on distribution of Scops Owl Otus scops in the wider area of Kras (SW Slovenia)

Table 3: Statistical parameters of environmental variables for unoccupied and occupied settlements in the wider area of Kras, measured at circular plots with a 500 m radius around the centres of settlements. Variables with statistically significant difference between groups $(P<0.05)$ are in boldface.

Tabela 3: Statistični parametri okoljskih spremenljivk za nezasedena in zasedena naselja na širšem območju Krasa; statistična enota so krogi z radijem 500 m okoli središč naselij. Spremenljivke s statistično značilno razliko med skupinama $(P<0.05)$ so označene s krepkim tiskom.

\begin{tabular}{|c|c|c|c|}
\hline $\begin{array}{l}\text { Environmental variable/ } \\
\text { Okoljska spremenljivka }\end{array}$ & $\begin{array}{c}\text { Unoccupied } \\
\text { settlements/ } \\
\text { Nezasedena naselja } \\
(\mathrm{n}=66)\end{array}$ & $\begin{array}{c}\text { Occupied } \\
\text { settlements/ } \\
\text { Zasedena naselja } \\
(\mathrm{n}=63)\end{array}$ & $P$ \\
\hline Vineyards / Vinogradi (\%) & $3.8 \pm 6.2$ & $5.7 \pm 6.6$ & 0.003 \\
\hline $\begin{array}{l}\text { Extensively managed orchards/ } \\
\text { Ekstenzivni oz. travniški sadovnjaki (\%) }\end{array}$ & I.I $\pm \mathrm{I} . \mathrm{I}$ & $\mathrm{I} . \mathrm{O} \pm \mathrm{I} . \mathrm{O}$ & 0.475 \\
\hline Permanent grasslands / Trajni travniki (\%) & $3 \mathrm{I} .3 \pm 15.0$ & $3 I .5 \pm 11.5$ & $0.7 \mathrm{I} 3$ \\
\hline $\begin{array}{l}\text { Agricultural land in early succesional stages of forest/ } \\
\text { Kmetijska zemljišča v zaraščanju (\%) }\end{array}$ & $3.1 \pm 3.0$ & $4 \cdot 4 \pm 7 \cdot 4$ & 0.682 \\
\hline $\begin{array}{l}\text { Forest edge ( } 50 \text { m wide }) / \\
\text { Gozdni rob ( } 50 \text {-metrski pas v gozd) }(\%)\end{array}$ & $25.7 \pm \mathrm{II} .7$ & $27.0 \pm 10.8$ & 0.785 \\
\hline Dense forest / Notranji gozd (\%) & $\mathrm{I} 3.2 \pm \mathrm{IO} .2$ & $\mathrm{I} 2.7 \pm \mathrm{II} .7$ & $0.45 \mathrm{I}$ \\
\hline $\begin{array}{l}\text { Landscape mosaics (number of land-use polygons)/ } \\
\text { Mozaičnost krajine (št. vseh poligonov rabe tal) }\end{array}$ & $88.3 \pm 27.5$ & $103 \cdot 3 \pm 32.7$ & 0.010 \\
\hline $\begin{array}{l}\text { Landscape heterogeneity (number of different land-use types)/ } \\
\text { Heterogenost krajine (št. različnih vrst rabe zemljišč }\end{array}$ & $9 \cdot 3 \pm 1.6$ & $9.5 \pm \mathrm{I} .4$ & 0.210 \\
\hline Length of hedgerows / Dolžina mejic (m) & $3330 \pm 2540$ & $3902 \pm 2889$ & 0.256 \\
\hline $\begin{array}{l}\text { Average size of arable fields/ } \\
\text { Povprečna velikost ornih površin }\left(\mathrm{m}^{2}\right)\end{array}$ & $\mathrm{I} 847 \pm \mathrm{I} 302$ & $1572 \pm 836$ & 0.910 \\
\hline $\begin{array}{l}\text { Average annual air temperature/ } \\
\text { Povprečna letna temperatura zraka }\left({ }^{\circ} \mathrm{C}\right)\end{array}$ & $\mathrm{II} .3 \pm \mathrm{I} .2$ & II.5 \pm I.I & 0.409 \\
\hline $\begin{array}{l}\text { Average annual precipitation/ } \\
\text { Povprečna letna količina padavin }(\mathrm{mm})\end{array}$ & I $549 \pm$ I 2 & $\mathrm{I} 53 \mathrm{I} \pm \mathrm{I} 5 \mathrm{I} 5$ & 0.708 \\
\hline Altitude / Nadmorska višina (m) & $344.2 \pm \mathrm{I} 68 . \mathrm{I}$ & $319.4 \pm 142.6$ & 0.090 \\
\hline Slope / Naklon površja $\left({ }^{\circ}\right)$ & $8.9 \pm 4.1$ & $8.6 \pm 4.6$ & 0.378 \\
\hline $\begin{array}{l}\text { Settlements with predominant } S \text { and SW-facing slopes/ } \\
\text { Naselja s prevladujočo J in JZ ekspozicijo (\%) }\end{array}$ & 47 & 52.4 & * 0.439 \\
\hline Number of old buildings / Število starih stavb & $40.6 \pm 29.3$ & $56.0 \pm 33.8$ & 0.004 \\
\hline Potentially suitable habitat / Potencialno ustrezni habitat (\%) & $49.9 \pm 15.0$ & $51.4 \pm 16.3$ & 0.528 \\
\hline $\begin{array}{l}\text { Distance from highway/ } \\
\text { Oddaljenost od avtoceste oz. hitre ceste (m) }\end{array}$ & $3669 \pm 2868$ & $5889 \pm 3044$ & $<0.001$ \\
\hline
\end{tabular}

* Difference between groups tested by Pearson Chi-square test / Razlika med skupinama testirana s Pearsonovim $\chi^{2}$-testom

If there is linearity with the logit, the parameter estimate $(b)$ for each class of the newly categorised explanatory variable should increase or decrease in roughly linear steps. If the relation was clearly nonlinear, this variable was discretized (GARSON 2009). Descriptive statistics were used to describe the mean and standard deviation values of the environmental variables for the two groups (occupied/unoccupied sites), while differences in mean values between the two groups were analyzed with the Mann-Whitney U test (SPSS 2008).

\section{Results}

\subsection{Abundance, spatial distribution and density of Scops Owl}

In 2006, 180 males were recorded; 163 of them within IBA Kras and 144 within SPA Kras. On average, $1.2 \pm 1.8$ males per settlement were recorded (range $0-12$ ). Settlements with the highest number of males were Brestovica pri Komnu (12 calling males), Komen (8), Gorjansko (7), Golac (6), Kostanjevica 
Table 4: Logistic regression model for habitat selection at the settlement scale: effect of environmental variables on Scops Owl Otus scops occurrence in the wider area of Kras

Tabela 4: Model logistične regresije za izbor habitata na nivoju naselij: vpliv okoljskih spremenljivk na pojavljanje velikega skovika Otus scops na širšem območju Krasa

\begin{tabular}{|c|c|c|c|c|c|c|c|c|}
\hline $\begin{array}{l}\text { Environmental variable/ } \\
\text { Okoljska spremenljivka }\end{array}$ & $\begin{array}{l}\text { Parameter } \\
\text { estimate/ } \\
\text { Ocena } \\
\text { parametra } \\
\quad(b)\end{array}$ & $\begin{array}{l}\text { St. } \\
\text { error/ } \\
\text { Stand. } \\
\text { napaka }\end{array}$ & $\begin{array}{l}\text { Wald } \\
\text { statistics/ } \\
\text { Wald } \\
\text { statistika }\end{array}$ & df & $P$ & $\begin{array}{l}\text { Odds } \\
\text { ratio/ } \\
\text { Razmerje } \\
\text { obetov } \\
(\operatorname{Exp}(b))\end{array}$ & \multicolumn{2}{|c|}{$\begin{array}{c}95 \% \text { C.I. for } \\
\text { odds ratio / } 95 \% \\
\text { interval zaupanja } \\
\text { za razmerje } \\
\text { obetov }\end{array}$} \\
\hline $\begin{array}{l}\text { * Distance from highway/ } \\
\text { Oddaljenost od avtoceste } \\
\text { oz. hitre ceste: }\end{array}$ & & & 26.096 & 3 & $<0.001$ & & & \\
\hline $2106-4077 \mathrm{~m}$ & -0.744 & 0.723 & I.058 & I & 0.304 & 0.475 & O.IIS & I.96I \\
\hline $4078-6897 \mathrm{~m}$ & $\mathrm{I} .47 \mathrm{I}$ & 0.633 & 5.407 & I & 0.020 & 4.353 & 1.260 & 15.037 \\
\hline$\geq 6898 \mathrm{~m}$ & $2.6 \mathrm{I} 8$ & 0.663 & 15.609 & I & $<0.001$ & I3.703 & 3.740 & 50.207 \\
\hline $\begin{array}{l}\text { * Length of hedgerows/ } \\
\text { Dolžina mejic: }\end{array}$ & & & I0.34I & 3 & 0.016 & & & \\
\hline $\mathrm{I} 60 \mathrm{I}-3000 \mathrm{~m}$ & I. 827 & 0.636 & 8.247 & I & 0.004 & 6.218 & I. 786 & 21.643 \\
\hline $300 \mathrm{I}-4800 \mathrm{~m}$ & 0.197 & 0.680 & 0.084 & I & 0.773 & I. 217 & $0.32 \mathrm{I}$ & 4.618 \\
\hline$\geq 480 \mathrm{Im}$ & 1.300 & $0.66 \mathrm{I}$ & 3.873 & I & 0.049 & 3.669 & 1.005 & I3.394 \\
\hline $\begin{array}{l}\text { Average annual air } \\
\text { temperature / Povprečna } \\
\text { letna temperatura zraka }\end{array}$ & 0.552 & 0.245 & 5.057 & I & 0.025 & I.737 & I.073 & $2.8 \mathrm{IO}$ \\
\hline $\begin{array}{l}\text { Number of old buildings/ } \\
\text { Število starih stavb }\end{array}$ & 0.014 & 0.007 & 3.554 & I & 0.059 & I.OI 4 & 0.999 & 1.029 \\
\hline Constant / Konstanta & -8.716 & 2.916 & 8.934 & I & 0.003 & 0.000 & & \\
\hline
\end{tabular}

* Discrete variable; reference class is the first class ( $\leq 2105 \mathrm{~m}$ from highway, $\leq 1600 \mathrm{~m}$ of hedgerows) / Kategorična spremenljivka; referenčni razred je prvi razred ( $\leq 2105 \mathrm{~m}$ od avtoceste oz. hitre ceste, $\leq 1600 \mathrm{~m}$ mejic)

na Krasu (5), Ivanji Grad (5) and Podgorje (5). Crude density was 0.3 males $/ \mathrm{km}^{2}$ and ecological density was 1.0 males $/ \mathrm{km}^{2}$.

In 2008, we recorded 167 males (158 within IBA Kras and 133 within SPA Kras). On average, $1.1 \pm 1.8$ males per settlement were recorded (range $0-12$ ). Settlements with the largest number of males in 2008 were Podgorje (12 calling males), Brestovica pri Komnu (9), Ivanji Grad (7), Gorjansko (7), Komen (5), Preserje pri Komnu (5), Črnotiče (5) and Rakitovec (5). Crude density was 0.3 males $/ \mathrm{km}^{2}$ and ecological density was 0.9 males $/ \mathrm{km}^{2}$.

Distribution pattern of males was clumped in 2006 $\left(R_{n}=0.511, z<-1.96\right)$ and in $2008\left(R_{n}=0.598, z\right.$ $<-1.96)$, respectively. Roughly, $82 \%$ of calling males were recorded within the settlements (within a $500 \mathrm{~m}$ radius from the settlement centres).

In 2006, the population was concentrated in four areas within the study area: (1) western part of the Kras plateau (with the highest densities in the villages of Komen, Gorjansko, Brestovica pri Komnu), (2) central part of the Kras plateau (with the highest densities in the villages of Ponikve, Dutovlje and Kazlje), (3) Kraški rob, and (4) Čičarija plateau (Golac and surrounding villages). In, 2008 core-areas with the highest densities of Scops Owls were on: (1) western part of the Kras plateau (Komen, Gorjansko, Brestovica pri Komnu), (2) central part of the Kras plateau (Dobravlje), and (3) Podgorski kras plateau (Podgorje) (Figure 2).

\subsection{Habitat selection at the regional scale}

A total of 347 males recorded in 2006 an 2008 were distributed in 11 of the 25 land-use types (MKGP 2007). Land-use type "Olive groves” had a very small proportion of the total area and only one male recorded, so we excluded it from the analysis to meet the assumptions proposed by $\mathrm{Neu}$ et al. (1974). Chi-square goodness-of-fit test showed significant difference between the utilization and availability of the land-use types $\left(\chi^{2}=530.7\right.$, critical value $=16.9, \mathrm{df}=9$, $P<0.01)$, confirming that Scops Owl in the wider 
T. ŠušmeLJ: The impact of environmental factors on distribution of Scops Owl Otus scops in the wider area of Kras (SW Slovenia)

Table 5: Statistical parameters of environmental variables for unoccupied and occupied census plots in the wider area of Kras, measured at circular plots with a $200 \mathrm{~m}$ radius from the census points. Variables with statistically significant difference between groups $(P<0.05)$ are in boldface.

Tabela 5: Statistični parametri okoljskih spremenljivk za nezasedene in zasedene popisne ploskve na širšem območju Krasa; statistična enota so krogi z radijem 200 m okoli popisnih točk. Spremenljivke s statistično značilno razliko med skupinama $(P$ $<0.05)$ so označene s krepkim tiskom.

Environmental variable/

Okoljska spremenljivka

Unoccupied census
plots / Nezasedene
popisne ploskve
(n = 185)

Fields / Njive (\%)

Vineyards / Vinogradi (\%)

Extensively managed orchards/

Ekstenzivni oz. travniški sadovnjaki (\%)

Permanent grasslands / Trajni travniki (\%)

Agricultural land in early succesional stages of forest/

Kmetijska zemljišča v zaraščanju (\%)

Forest edge ( $50 \mathrm{~m}$ wide)/

Gozdni rob (50-metrski pas v gozd) (\%)

Dense forest / Notranji gozd (\%)

Landscape mosaics (number of land-use polygons)/

Mozaičnost krajine (št. vseh poligonov rabe tal)

Landscape heterogeneity (number of different land-use types) / Heterogenost krajine (št. različnih vrst rabe zemljišč)

Length of hedgerows / Dolžina mejic (m)

Average annual air temperature/

Povprečna letna temperatura zraka $\left({ }^{\circ} \mathrm{C}\right)$

Average annual precipitation/

Povprečna letna količina padavin $(\mathrm{mm})$

\section{Altitude / Nadmorska višina (m)}

Slope / Naklon površja $\left({ }^{\circ}\right)$

Census plots with predominant $S$ and SW-facing slopes/

Popisne ploskve s prevladujočo J in JZ ekspozicijo (\%)

Number of old buildings / Število starih stavb

Potentially suitable habitat / Potencialno ustrezni habitat (\%)

Distance from highway/

Oddaljenost od avtoceste oz. hitre ceste (m)

\section{Occupied census \\ plots / Zasedene \\ popisne ploskve $\left(\mathrm{n}=148^{* *}\right)$}

P

\footnotetext{
Difference between groups tested by Pearson Chi-square test / Razlika med skupinama testirana s Pearsonovim $\chi^{2}$-testom

** Occupied plots were weighted with the number of males within the plot / Zasedene popisne ploskve smo obtežili s številom samcev v krogu
}

area of Kras actually selects and avoids certain land-use types. Selectivity index reflects strong preference for built-up areas and open agricultural land (extensively managed orchards, vineyards, permanent grasslands) and avoidance of dense forest and agricultural land with scattered forest trees (Table 2).

\subsection{Habitat selection at the settlement scale}

Parameters of four variables differed significantly between occupied and unoccupied settlements.
Occupied settlements were characterized by more vineyards, higher landscape mosaics, more old buildings and larger distance from the highway (Table 3).

Logistic regression model predicted that at the settlement scale the Scops Owl occurrence was best clarified by three variables: (1) larger distance from the highway, (2) longer length of hedgerows, and (3) higher average annual air temperature. Variable "number of old buildings" was not statistically significant (Table 4). Distance from the highway was by far the most important predictor; probability of 
Table 6: Logistic regression model for habitat selection at the territory scale: effect of environmental variables on Scops Owl Otus scops occurrence in the wider area of Kras

Tabela 6: Model logistične regresije za izbor habitata na nivoju teritorija: vpliv okoljskih spremenljivk na pojavljanje velikega skovika Otus scops na širšem območju Krasa

\begin{tabular}{|c|c|c|c|c|c|c|c|c|}
\hline $\begin{array}{l}\text { Environmental variable/ } \\
\text { Okoljska spremenljivka }\end{array}$ & $\begin{array}{l}\text { Parameter } \\
\text { estimate/ } \\
\text { Ocena } \\
\text { parametra } \\
\quad(b)\end{array}$ & $\begin{array}{l}\text { St. } \\
\text { error/ } \\
\text { Stand. } \\
\text { napaka }\end{array}$ & $\begin{array}{l}\text { Wald } \\
\text { statistic/ } \\
\text { Wald } \\
\text { statistika }\end{array}$ & $\mathrm{df}$ & $P$ & $\begin{array}{l}\text { Odds } \\
\text { ratio/ } \\
\text { Razmerje } \\
\text { obetov } \\
(\operatorname{Exp}(b))\end{array}$ & \multicolumn{2}{|c|}{$\begin{array}{l}95 \% \text { C.I. for } \\
\text { odds ratio/ } \\
95 \% \text { interval } \\
\text { zaupanja za } \\
\text { razmerje obetov }\end{array}$} \\
\hline $\begin{array}{l}\text { * Distance from highway/ } \\
\text { Oddaljenost od avtoceste } \\
\text { oz. hitre ceste: }\end{array}$ & & & 33.943 & 3 & $<0.001$ & & & \\
\hline $200 \mathrm{I}-4000 \mathrm{~m}$ & 0.106 & 0.427 & 0.062 & I & 0.804 & I.I 2 & $0.48 \mathrm{I}$ & 2.568 \\
\hline $400 \mathrm{I}-6000 \mathrm{~m}$ & I.69I & 0.405 & I 7.393 & I & $<0.001$ & 5.424 & 2.450 & I2.006 \\
\hline$\geq 600 \mathrm{I}$ & I. 708 & 0.375 & $20.73 \mathrm{I}$ & I & $<0.001$ & 5.517 & 2.645 & II.506 \\
\hline $\begin{array}{l}\text { * Number of old buildings/ } \\
\text { Število starih stavb: }\end{array}$ & & & 33.148 & 3 & $<0.001$ & & & \\
\hline$I-9$ & I. 528 & 0.408 & I 4.020 & I & $<0.001$ & 4.608 & $2.07 \mathrm{I}$ & I0.254 \\
\hline IO-24 & I. 357 & $0.4 \mathrm{I} 2$ & $10.85 \mathrm{I}$ & I & O.OOI & 3.885 & I.733 & 8.710 \\
\hline$\geq 25$ & 2.453 & 0.428 & 32.782 & I & $<0.001$ & II. 624 & 5.020 & 26.918 \\
\hline $\begin{array}{l}\text { * Landscape mosaics/ } \\
\text { Mozaičnost krajine: }\end{array}$ & & & I0.326 & 3 & 0.016 & & & \\
\hline $2 I-28$ & I.I $2 \mathrm{I}$ & 0.399 & 7.887 & I & 0.005 & 3.069 & I. 403 & 6.712 \\
\hline $29-34$ & I. 227 & 0.430 & 8.136 & I & 0.004 & $3 \cdot 4 \mathrm{I} \mathrm{I}$ & I. 468 & 7.924 \\
\hline$\geq 35$ & 1.085 & 0.407 & 7.098 & I & 0.008 & 2.960 & I. 332 & 6.577 \\
\hline Constant / Konstanta & -3.612 & 0.515 & 49.270 & I & $<0.001$ & 0.027 & & \\
\hline
\end{tabular}

* Discrete variable; reference class is the first class ( $\leq 2000 \mathrm{~m}$ distance from highway, 0 old buildings, $\leq 20$ land-use polygons) / Kategorična spremenljivka; referenčni razred je prvi razred $(\leq 2000 \mathrm{~m}$ od avtoceste oz. hitre ceste, 0 starih stavb, $\leq 20$ poligonov rabe tal)

Scops Owl occurrence started to increase statistically significant when the distance was larger than ca. 4 $\mathrm{km}$, and was 14 -folds greater in settlements, which are at least $7 \mathrm{~km}$ away from the highway compared to settlements right next to it $(\leq 2105 \mathrm{~m})$. The described logistic model correctly classified $73.6 \%$ of the cases (76.2\% of occupied and $71.2 \%$ of unoccupied settlements).

\subsection{Habitat selection at the territory scale}

At the territory scale, differences between occupied and unoccupied census plots were statistically significant in eight variables. Occupied census plots were characterized by more fields, vineyards and extensively managed orchards, with higher landscape mosaics and landscape heterogeneity, with lower altitude, greater availability of old buildings and larger distance from the highway (Table 5).

Logistic regression analysis predicted that at the territory scale the occurrence of Scops Owl was best clarified by three variables: (1) larger distance from the highway, (2) greater number of old buildings, and (3) higher landscape mosaics. Probability of Scops Owl occurrence increased statistically significant in areas at least $4 \mathrm{~km}$ away from the highway (compared to areas which are right next to the highway), while further increase of distance did not contribute to greater probability. Variable "number of old buildings" in the model indicates that the probability for occurrence of the species increased gradually with the increased number of old buildings and was at its maximum in patches (census points with a $200 \mathrm{~m}$ radius), which contain 25 or more old buildings. Variable "landscape mosaics" in the model predicts that probability of Scops Owl occurrence is 3-folds greater in patches with higher landscape mosaics (with 21 and more polygons of land-use) compared to patches with lower landscape mosaics ( $\leq 20$ polygons). The described logistic model correctly classified $74.5 \%$ of cases $(70.9 \%$ of occupied and $77.3 \%$ of unoccupied census plots). 
T. ŠušmeLJ: The impact of environmental factors on distribution of Scops Owl Otus scops in the wider area of Kras (SW Slovenia)

\section{Discussion}

Systematic and comprehensive monitoring of Scops Owl' population in the wider area of Kras started in 2006 and continued in 2008 (and 2010, Denac et al. 2010). During these three surveys, the population varied between 120-180 males. Therefore, the preliminary population estimate in IBA Kras (300-600 pairs; Trontelj 2000) was probably overestimated. Further censuses are required to produce long-term population trend estimates. In 2011, the last part of Slovenia, where data on numbers were lacking (Slovenian Istria), was surveyed for Scops Owl (HANŽEL et al. 20I I), so now we can definitely conclude that the population of Scops Owl in the wider area of Kras makes the largest local population of this species in Slovenia.

Most males were recorded in villages and agricultural land in their surroundings, while some individual males were also registered on the forest edge or in the open agricultural land far away from settlements (KMECl \& Š ETina 2008). Since roughly $82 \%$ of males were recorded within the settlements, Scops Owl can be considered a highly synanthropic species. In some settlements, the distances between the individual males were very small, e.g. from 50 to $100 \mathrm{~m}$ in Kazlje, Ivanji Grad and Preserje pri Komnu, indicating on formation of calling groups (e.g. SACCHI et al. I999, Štumberger 2000, Vrezec 200 I, Denac 2003, Marchesi \& Sergio 2005).

Spatial distribution of the Scops Owl population did not change significantly between 2006 and 2008, what may indicate more favourable conditions and high quality of areas occupied both years (SERGIO \& NEwTON 2003). The only substantial change was a shift of a local population from Kraški rob towards the less warm Podgorski kras plateau. High densities of Scops Owl on Kraški rob can be explained by numerous factors: (1) cavities and shelves in the rocky cliffs provide suitable breeding niches (Lipej et al. 2005, T. Minelič pers. comm.), (2) the favourable microclimate on the S- and SW-facing slopes probably results in greater prey availability, e.g. grasshoppers (GALEOTTI \& GARIbOldi 1994) and suits a thermophilic species such as the Scops Owl (Cramp i998), and (3) 3-4 pairs of Eagle Owl Bubo bubo nest in the rocky walls of Kraški rob regularly (RuBinič et al. 2004, RUBinič et al. 2009, Denac et al. 2010) and as Tawny Owls Strix aluco avoid the territories of Eagle Owl (Galeotti \& Gariboldi i 994, Benussi et al. I997), the predation pressure by this species might be much smaller in some parts of Kraški rob. It is surprising that a small isolated population was observed in the coldest and wettest parts of the study area, that is in village of Golac (640 $\mathrm{m}$ a.s.l.) and surrounding small villages on the Čičarija plateau. Scops Owl might have found favourable conditions in those villages due to high availability of decaying and abandoned rural houses, potentially suitable for nesting, many hedgerows, scattered trees, extensively managed grasslands in different successional stages, and sufficient distance $(3.5 \mathrm{~km})$ from the very busy road leading through the Matarsko podolje Valley. Another surprising discovery was the two males found at about $800 \mathrm{~m}$ a.s.l. in vast dry grasslands between Kojnik and Golič on the Čičarija plateau. Since Scops Owls usually avoid extensive open areas (Cramp I998), their occurrence there could possibly be attributed to locally very high abundance of grasshoppers and other insects in overgrown sinkholes in that area (KoCE 2007). Abundance of grasshoppers in SW Slovenia appears to be much greater in karst areas on limestone bedrock compared to the flysch bedrock (Koce 2007), what is probably one of the factors for Scops Owl's absence on the southern edge of the Vipava River Valley, where dominant north-facing slopes are less warm and the soil on flysch bedrock is more humid.

Crude density of Scops Owl was quite similar to that in Goričko (0.2 males $/ \mathrm{km}^{2}$, Denac et al. 20 I I в) and at Ljubljansko barje (0.4 males $/ \mathrm{km}^{2}$, Denac et al. 20 Io). Among these three sites, ecological density was the highest in the wider area of Kras owing to the specific landscape structure (small surface area of suitable habitat, large forest areas). Similar crude densities as in our study area were recorded in some Mediterranean parts of Europe, e.g. on the small Croatian island of Šolta (0.25 male $/ \mathrm{km}^{2}$, MužInIČ \& PURGer 2008) and in the Italian Alps in the Vallarsa Valley (0.5-0.6 male/ $\mathrm{km}^{2}$ ), which is characterized by a particularly warm and dry climate and a mosaic landscape of extensive cultivations (MARCheSI \& SERGIO 2005). In the other parts of the Mediterranean, crude densities were much higher compared to our study area: 0.7-1.4 males $/ \mathrm{km}^{2}$ on Oleron island in France (Hardouin et al. 2007) and 1.0-1.5 males $/ \mathrm{km}^{2}$ on the Croatian Pelješac peninsula (VRezec 200I). Surprisingly, very high crude densities were also recorded locally in Central Europe. For example, in the upper part of the Rhone Valley in Central Wallis, Switzerland, the overall densities observed in 1986 and 1988 were 5.67.6 males $/ \mathrm{km}^{2}$, but this population underwent a steep decline in the second half of the $20^{\text {th }}$ century and is on the verge of extinction (ARLETTAZ et al. I99I).

Results of habitat selection study at the three spatial scales can be summarized in a conclusion that a suitable habitat for Scops Owl in the wider area of 
Kras constitutes areas that as far as possible meet the following conditions: (1) have sufficient availability of open habitats (extensively managed orchards, vineyards, permanent grasslands), (2) have sufficient availability of old buildings, potentially suitable for nesting, (3) are far enough from the heavy-traffic roads (highways), (4) have well-preserved traditional agricultural landscape (landscape mosaics, hedgerows), and (5) have an average annual air temperature of at least $11.5^{\circ} \mathrm{C}$.

At the regional scale, the observed distribution pattern of Scops Owls and the order of preferred land-use types are in tight connection with land-use pattern in the study area. Forest covers more than half of the surface and is obviously not a suitable habitat for Scops Owl (Bavoux et al. I997, Denac 2000A, 2003 \& 2009, KMeCl \& Š ETINA 2008, this study), while settlements with surrounding agricultural land constitute "islands" of suitable habitat, over which the Scops Owl is distributed. The most preferred were extensively managed orchards, which are usually located right next to the houses or villages, then a little further are a little less preferred vineyards, small fields and permanent grasslands. Usually, the most distant from the settlements are agricultural land with scattered forest trees and dense forest, which Scops Owl avoids. We suppose that Scops Owl avoids dense forests, as they are too cold and humid for its main prey, the grasshoppers (ARLETtAz et al. I99I, Keller \& Parrag i 996, Marchesi \& Sergio 2005, Hein et al. 2007, Rubinič et al. 2008, Muraoka 2009) and possibly because of predation pressure from the Tawny Owl (Galeotti \& Gariboldi i 994, MarChesi \& Sergio 2005). The very high preference for extensively managed orchards is probably related to their suitability for foraging and nesting, although their availability in the study area is very small $(0.3 \%$, MKGP 2007) and no nest in a tree hole has been found yet. Based on very high preference for built-up areas, we suppose that in the study area more Scops Owls nest in old buildings than in tree-holes. Anyway, further field studies are needed to test this hypothesis. Preference for permanent grasslands is obvious, as they are very rich in insects, including grasshoppers (HeIN et al. 2007). Preference for vineyards is more difficult to interpret. It may indicate their suitability as foraging habitat (Lipej 2000, Malus 2007) or as breeding habitat (Galeotti \& Gariboldi i 994, Benussi et al. I997, Lipej 2000). In the nearby Rosandra Valley (Italy), Scops Owl demonstrated clear preference towards vineyards, too, although availability of this habitat type was very small (GALEOTTI \& GARIBOLDI I994). Lipej (2000) stressed the importance of the surroundings of vineyards, where Scops Owl may nest in stonewalls, old buildings, hedgerows or tree holes. It is also possible that the observed preference for vineyards is fictive because of inaccurate entry of males' locations on the map by observers. Vineyards in the study area are mainly small, narrow and located in a mosaic agricultural landscape, therefore it is difficult to accurately determine the location of individuals, especially at night. The variable "Vineyards" was strongly correlated with the variables "Landscape mosaics" and "Landscape heterogeneity", what may indirectly indicate actual importance of landscape heterogeneity and mosaics for Scops Owl. In addition, the comparison of two main wine-producing areas within the study area showed big differences in Scops Owl presence. On the southern edge of the Vipava River Valley (e.g. settlements of Tabor, Dornberk, Gradišče nad Prvačino) Scops Owl was not recorded in neither of the years, while in the viticultural area of the central Kras plateau it was quite common. Due to the higher relative humidity (water evaporating from the Vipava River), vineyards in the Vipava Valley are more intensively sprayed by pesticides than vineyards on the Kras plateau (J. ŽGUR pers. comm.), so higher pesticide-use can be a factor contributing to the absence of Scops Owl in the Vipava River Valley. Comparison of these two sites also indicates many other landscape differences. Viticultural settlements on the southern edge of Vipava Valley have less hedgerows, less permanent grasslands, more dense forests, smaller landscape mosaics, a much smaller percentage of the S- and SW-facing slopes and are closer to highway than viticultural settlements on the Kras plateau. Obviously, multiple aspects interact and influence the Scops Owl occurrence, and not just one variable (vineyards). However, wine growing in the areas of Scops Owl's occurrence should not be too intensive. The rapid expansion of intensively managed vineyards was identified as the main factor for a steep decline of Scops Owl populations in Northern Italy (SACCHi et al. 1999) and Switzerland (ArLetTAZ et al. I99I).

Scops Owl preferably occupied sites with greater availability of old buildings, especially when selecting a patch for a territory. This may indicate that Scops Owl uses old buildings for nesting or there is some other indirect reason for such result, e.g. nesting in old trees in gardens next to houses. Denac (2009), for example, reports that at Ljubljansko barje Scops Owls regularly called from large old trees in farmyards (e.g. Horse Chestnut Aesculus hippocastanum, Largeleaved Lime Tilia platyphyllos, Small-leaved Lime Tilia cordata), and that two nests were found in extensively 
T. ŠušmelJ: The impact of environmental factors on distribution of Scops Owl Otus scops in the wider area of Kras (SW Slovenia)

managed orchards, located next to houses. In our study area, no nests have been found in buildings yet. T. Minelič (pers. comm.) reports that 2-3 pairs of Scops Owl were calling from buildings in the village of Osp under Kraški rob during the whole breeding season of 1993 , indicating that they were probably breeding in them. Nesting in old buildings is very common in the Italian Alps (Vallarsa), where most nests were found in walls of inhabited buildings, in cracks at the junction between the outer wall and roof and in holes within church towers (MARCHESI \& SERgio 2005). As proposed by Marchesi \& Sergio (2005), nesting in buildings seems to have many advantages. Firstly, cavities in buildings may be relatively cool during hot days, preventing nestlings from overheating, while the heat released at night by rocky walls may compensate for heat loss at night and provide a more favourable thermal environment for nesting (MARCHESI \& SERGIO 2005). Secondly, placing the nest within the village may minimize distance to hunting areas in its vicinity during breeding, what is likely to be important for Scops Owl because of a high frequency of prey delivery to the nest (MARCheSI \& Sergio 2005, MuraOKa 2009). Thirdly, as observed by VRezeC (200I), roadside lamps, which are mainly restricted to settlements, attract large numbers of insects and consequently Scops Owls. In bigger settlements of the study area (e.g. Sežana, Divača, Hrpelje, Kozina), Scops Owl was mainly absent, probably due to the lack of breeding niches and foraging areas. In the last few decades, urbanisation changed the architecture of settlements and rural houses very much (ZELNIK 2008). Building of new houses, loss of abandoned rural buildings, renovation of old houses in the way which does not maintain the breeding niches in the walls, and removal of old (fruit) trees from gardens together with introduction of ornamental shrubs and dwarf trees, all lead to reduced availability of nests for Scops Owl (Rubinič et al. 2008, Denac 2009).

Our analyses showed that Scops Owl consistently avoided highways. Daily traffic on the motorway at the Razdrto-Socerb section is estimated at 17,000 vehicles/day, while traffic density on the RazdrtoNova Gorica trunkroad is estimated at 7,500 vehicles/ day and is still increasing (DARS 2007). The area affected by road traffic, within which the Scops Owl was absent or less common, was ca. 4,000 m away from the highway, with some exceptions due to more favourable topography (e.g. Osp village is ca. $1 \mathrm{~km}$ distant from the highway, but as it is situated under the rocky walls of Kraški rob, the noise is reduced there a great deal; three males were recorded in 2006 and 2008). Similar effect-distances of 2,000-3,000 m from the road have also been reported for numerous grassland and woodland bird species (Reijnen et al. I996, Forman et al. 2002). Scops Owl is acoustically very active, i.e. using calls for recognition between individuals and for maintenance of their territories while using hearing to locate their prey (HeLlen \& Arlettaz i 994, Galeotti et al. 1997). Therefore, we estimate that the main cause for the negative impact of roads is traffic noise, beside car-collisions (BAvoux et al. 1997, Denac 2000B, Pavelčín 2000, Marchesi \& Sergio 2005). The reason for Scops Owls colliding with vehicles could be in its low-flight, as one of the preferred foraging strategies is flying onto bush crickets, beetles and butterflies within a layer of 2-6 $\mathrm{m}$ above the ground (Šotnár et al. 2008). As roads obviously have an extremely negative effect on Scops Owl, this aspect should be subjected to further studies. Indicators of traditional farmland, such as length of hedgerows and landscape mosaics, predicted Scops Owl occurrence at the settlement and territory scales. Farmland rich in hedgerows may benefit Scops Owl in providing hunting perches, nesting holes, places for day roosting and a diversified landscape rich in prey (Rubinič et al. 2008, Denac 2009, Sergio et al. 2009). Similarly, high degree of landscape mosaics is important for smaller species such as the Scops Owl (Streit \& Kalotás i99i, Galeotti \& Gariboldi i 994, Keller \& Parrag 1996), since it offers welldiversified entomofauna in small area (e.g. MarChesi \& Sergio 2005). Arlettaz \& Fournier (i993) even noticed a difference in the choice of prey between the sexes, which possibly indicates spatial segregation in the hunting range. The authors suggested that females hunt in denser vegetation (woodland edges, hedgerows) and males in more open areas (meadows and pastures). All this probably explains, why during all three Scops Owl surveys (2006, 2008 and 2010) the species was absent in settlements on the southern edge of Vipava Valley, where expansion of intensive land-uses, especially vineyards and fruit plantations, accompanied by the removal of hedgerows, resulted in a habitat, unsuitable for Scops Owl. Such landscape changes are known to have a negative effect on populations of Tettigoniid grasshoppers (KöHLER I996).

As expected, variable average annual air temperature predicted Scops Owl occurrence at the settlement scale, since it is too robust to show microclimatic conditions at finer scales. Areas of relatively higher air temperature and lower precipitation correspond very well to areas with the highest densities of Scops Owl (e.g. western part of the Kras plateau, Kraški rob). This is probably due to higher availability of grasshoppers. 
(e.g. Arlettaz et al. i99i, Keller \& Parrag i996, Marchesi \& Sergio 2005, Rubinič et al. 2008, MURAOKA 2009), which are positively influenced by increased temperatures (HeIN et al. 2007). In the last two decades, average annual temperatures in Slovenia have increased significantly, being 0.5 to $1^{\circ} \mathrm{C}$ higher in all Slovene regions than the average temperatures between 1961 and 1990 (OGRIN 2004). Due to global warming, the species is most likely going to expand its present distribution to higher latitudes and altitudes across Slovenia (HuntLey et al. 2007), which has already been observed in Slovakia (KRIšTín \& KAŇUCH 2009).

Based on habitat selection analysis, the following conservation measures for Scops Owls in the wider are of Kras are recommended:

- promotion of extensive farming practices on permanent grasslands (low or no fertilizer use, ideally with one grassland harvest per year (SERGIO et al. 2009), or by low-intensity grazing systems),

- preservation of traditional mosaic landscape, especially in surroundings of villages,

- prevention from scrub-encroachment and afforestation,

- prevention from removal of semi-natural elements in traditional landscapes (hedgerows, stonewalls etc.),

- promotion of organic farming, especially for extensively managed orchards and vineyards (e.g. ecological wine-production, organic fruit production etc.),

- preservation of extensively managed orchards and other old trees with tree-holes, potentially suitable for nesting (e.g. hedgerows, willows in vineyards, chestnut avenues etc.),

- preservation of cavities in outer walls of buildings when they are renovated, or promotion of installation of nestboxes.

According to habitat requirements, the main threats to Scops Owl and its habitat in the wider area of Kras are: (1) traffic noise, (2) intensification of farmland, especially evident in the lower Vipava River Valley, (3) land abandonment, followed by scrub encroachment and forest expansion, resulting in loss of open habitat, which is a dominant process in the major part of the study area (TRONTELJ 2000), and (4) urbanisation of settlements and rural houses. We can conclude that in the long-term, Scops Owl population in the wider area of Kras is threatened if these negative trends continue.

Acknowledgments: The Scops Owl census was organised by DOPPS - BirdLife Slovenia. The census in 2006 was part of the project entitled "Natura
2000 for better quality of life (Natura Primorske)", which was funded by the European Union under the Community Initiative Programme INTERREG IIIA Slovenia-Italy 2000-2006, the Government Office for Local Self-Government and Regional Policy, and the Ministry of the Environment and Spatial Planning. The census in 2008 was implemented within the "Monitoring of populations of target bird species" project funded by the Ministry of the Environment and Spatial Planning. I am thankful to DOPPS - Birdlife Slovenia for providing the source data used in the research, especially to Andrej Figelj, the coordinator of the censuses. The censuses were carried out by the following volunteers and members of DOPPS - BirdLife Slovenia: Tomaž Berce, Alenka Bradač, Igor Brajnik, Petra Draškovič, Maarten de Groot, Katarina Groznik - Zeiler, Dare Fekonja, Vojko Havliček, Bojana Fajdiga, Andrej Figelj, Jernej Figelj, Marko Gregorič, Tomaž Hain, Jurij Hanžel, Lara Jogan Polak, Anže Kacin, Ivan Kljun, Primož Kmecl, Urša Koce, Ivan Kogovšek, Peter Krečič, Borut Kumar, Marijan Manfreda, Andrej Medved, Tomaž Mihelič, Borut Mozetič, Nevenka Pfajfar, Blaž Pipan, Slavko Polak, Aljaž Rijavec, Erik Šinigoj, Vilijana Šiškovič, Tanja Šumrada, Rajko Šušmelj, Eva Vukelič, Barbara Zakšek and Valerija Zakšek. I would also like to thank Dr Peter Trontelj, Dr Al Vrezec, Dr Primož Kmecl, Dr Klemen Jerina and Dr Andrej Blejec for many useful discussions and advices on methodology, as well as to anonymous reviewers for their valuable comments.

\section{Povzetek}

Cilj raziskave je bil odkriti ključne okoljske dejavnike, ki vplivajo na pojavljanje velikega skovika Otus scops na širšem območju Krasa (JZ Slovenija, 665 km²). $\mathrm{Na}$ tem območju je bil veliki skovik sistematično popisan v letih 2006 (180 kličočih samcev) in 2008 (167 kličočih samcev). Samci so bili razporejeni bodisi posamično bodisi gručasto, in sicer večinoma po naseljih in okoliških kmetijskih površinah, kar kaže na sinantropnost vrste. Navadna gostota je znašala 0,3 samca $/ \mathrm{km}^{2}$ v letih 2006 in 2008, ekološka pa 1,0 leta 2006 in 0,9 samca $/ \mathrm{km}^{2}$ leta 2008. Prostorska razporeditev populacije, z najvišjimi lokalnimi gostotami na zahodnem in osrednjem delu Krasa, Kraškem robu in Podgorskem krasu, se med popisnima letoma ni bistveno spremenila. Izbor habitata je bil analiziran na treh prostorskih nivojih (pokrajinski nivo, nivo naselij, nivo teritorija), na podlagi prostorskih podatkovnih slojev (22 okoljskih spremenljivk), z uporabo $\chi^{2}$-testa ujemanja 
T. ŠušmeLJ: The impact of environmental factors on distribution of Scops Owl Otus scops in the wider area of Kras (SW Slovenia)

in logistične regresije. Rezultati so pokazali, da na pokrajinskem nivoju veliki skovik izmed različnih vrst rabe tal prednostno izbira odprte habitate (ekstenzivne oz. travniške sadovnjake, pozidana zemljišča, vinograde ter trajne travnike), izogiba pa se strnjenega gozda in kmetijskih zemljišč, poraslih z gozdnim drevjem. Izmed naselij raje izbira tista, ki so bolj oddaljena od avtoceste oz. hitre ceste, imajo dobro ohranjeno tradicionalno kmetijsko krajino (več mejic) in višjo povprečno letno temperaturo zraka. Pri izbiri teritorija pa je bilo pojavljanje velikega skovika $\mathrm{v}$ tesni povezavi $\mathrm{z}$ večanjem oddaljenosti od avtoceste oz. hitre ceste, $\mathrm{z}$ večanjem števila starih stavb in z večanjem mozaičnosti krajine. Vrsto ogrožajo hrup s prometnih cest, izguba habitata zaradi opuščanja in intenziviranja kmetijske rabe ter (potencialno) pomanjkanje gnezdilnih mest znotraj naselja. Ukrepi za ohranitev vrste bi morali temeljiti na ohranjanju mozaične kmetijske krajine, spodbujanju ekstenzivne rabe zemljišč, preprečevanju širjenja zarasti in gozda ter vzdrževanju gnezdilnih niš znotraj naselij (dreves z dupli, lukenj v zidovih stavb).

\section{Literatura}

Arlettaz, R., Fournier, J., Juillard, M., Lugon, A., Rossel, D. \& Sierro, A. (I991): [Origins of decline of the relict population of Scops owl, Otus scops, in the Alps (southwestern Switzerland): an empirical approach.] pp. 15-30 In: Juillard M. (ed.): Rapaces Nocturnes. Actes $\mathrm{du} 30^{\mathrm{e}}$ Colloque interregional d'ornithologie, Porrentruy (Suisse), 2, 3 et 4 novembre 1990. Prangins, Switzerland. - Société romande pour l'étude et la protection des oiseaux. (in French)

Arlettaz, R. \& Fournier, J. (I993): [Does the Scops owl Otus scops show sexual segregation in prey selection?] Alauda 61 (4): 257-263. (in French)

ARSO (2007A): Povprečna letna temperatura zraka v obdobju 1971-2000. Vektorska karta. - Agencija RS za okolje, Ljubljana.

ARSO (2007B): Povprečna letna višina padavin v obdobju 1961-1990. Vektorska karta. - Agencija RS za okolje, Ljubljana.

Bavoux, C., Burneleau, G. \& Nicolau-Guillaumet, P. (I997): Scops Owl Otus scops. pp. 400-401 In: Hagemeijer, W.J.M. \& Blair, M.J. (eds.): The EBCC Atlas of European Breeding Birds. - T \& A D Poyser, London.

Benussi, E., Galeotti, P. \& Gariboldi, A. (i997): [The owl community (Strigiformes) from Val Rosandra (Carso triestino).] - Annales 11: 85-92. (in Italian)

BirdLife International (2004): Birds in Europe: population estimates, trends and conservation status. BirdLife Conservation Series No. 12. - BirdLife International, Cambridge.

Božıč, L. (2003): Mednarodno pomembna območja za ptice v Sloveniji 2. Predlogi Posebnih zaščitenih območij (SPA) v Sloveniji. Monografija DOPPS št. 2. - DOPPS - BirdLife Slovenia, Ljubljana.
Byers, C.R., Steinhorst, R.K. \& Krausman, P.R. (I984): Clarification of a technique for analysis of utilizationavailability data. - Journal of Wildlife Management 48: 1050-1053.

Clark, P.J. \& Evans, F.C. (I954): Distance to nearest neighbor as a measure of spatial relationships in populations. - Ecology 35 (4): 445-453.

Cramp, S. (ed.) (r 998): The Complete Birds of the Western Palearctic on CD-ROM. - Oxford University Press, New York.

DARS (2007): Prometne obremenitve v letih 2004 in 2005 ter napoved za leto 2010. - [http://www.dars.si/ Dokumenti/2-Obremenitve/prometne_obremenitve_ MAJ_2007[1].pdf], 11/5/2011

Denac, K. (2000A): Rezultati popisa velikega skovika Otus scops na Ljubljanskem barju v letu 1999. - Acrocephalus $21(98 / 99): 35-37$.

Denac D. (2000в): Veliki skovik Otus scops. - Acrocephalus 21 (98/99): 84-100.

Denac, K. (2003): Populacijska dinamika velikega skovika Otus scops na Ljubljanskem barju (osrednja Slovenija). Acrocephalus 24 (119): 127-133.

Denac, K. (2009): Habitat selection of Eurasian Scops Owl Otus scops on the northern border of its range, central Slovenia. - Ardea 97 (4): 535-540.

Denac, K., Božič, L., Rubinič, B., Denac, D., Mihelič, T., KMecl, P. \& Bordjan, D. (20IO): Monitoring populacij izbranih vrst ptic. Popisi gnezdilk in spremljanje preleta ujed spomladi 2010. Delno poročilo. Naročnik: Ministrstvo za okolje in prostor. - DOPPS, Ljubljana.

Denac, K., Mihelič, T., Božıč, L., Kmecl, P., Jančar, T., FigelJ, J. \& Rubinič, B. (20 I IA): Strokovni predlog za revizijo posebnih območij varstva (SPA) z uporabo najnovejših kriterijev za določitev mednarodno pomembnih območij za ptice (IBA). Končno poročilo. Naročnik: Ministrstvo za okolje in prostor. - DOPPS, Ljubljana.

Denac, K., Mihelič, T., Denac, D., Božıč, L., Kmecl, P. \& Bordjan, D. (20 I IB): Monitoring populacij izbranih vrst ptic. Popisi gnezdilk spomladi 2011 in povzetek popisov v obdobju 2010-2011. Končno poročilo. Naročnik: Ministrstvo za okolje in prostor. - DOPPS, Ljubljana.

ESRI (2005): ArcGIS, ver. 9.1. - ESRI, Redlands, CA.

Forman, R.T.T., Reineking, B. \& Hersperger, A.M. (2002): Road traffic and nearby grassland bird patterns in a suburbanizing landscape. - Environmental Management 29: 782-800.

Gabrijelčič, Z., Ušaj, H., Kodrič, I., Poženel, A., Gorkič, M. \& Osmuk, N. (1996): Vipavska dolina včeraj, danes, jutri. pp. 85-98 In: Mišičev vodarski dan 1996. Zbornik posvetovanja. 6 Dec 1996, Maribor. Vodnogospodarski biro Maribor.

Galeotti, P. \& Gariboldi, A. (I994): Territorial behaviour and habitat selection by the Scops owl Otus scops in a Karstic valley (N.E. Italy). pp. 501-505 In: MeYburg, B.U. \& ChANCELlor, R.D. (eds.): Raptor conservation today. - World Working Group on Birds of prey and owls, Berlin \& Pica Press, London.

Galeotti, P., Sacchi, R. \& Pirani, E. (I 997): Cooperative defence and intrasexual aggression in scops owls (Otus 
scops): calls responses to playback of male and female. Journal of Raptor Research 31: 353-357.

Galeotti, P. \& Sacchi, R. (200I): Turnover of territorial scops owls Otus scops as estimated by spectrographic analyses of male hoots. - Journal od Avian Biology 32: 256-262.

Garson, G.D. (2009): Logistic Regression (Statnotes: Topics in Multivariate Analysis). - [http://faculty.chass. ncsu.edu/garson/PA765/logistic.htm], 14/11/2009

Graf, R. (2005): Analysis of capercaillie habitat at the landscape scale using aerial photographs and GIS. Diss. ETH No. 15999. - Swiss Federal Institute of Technology ETH, Zürich.

GURS (2005): Državna pregledna karta merila 250.000 (DPK250_V): komunikacije. Vektorska vrsta podatka v SHP formatu. - Geodetska uprava RS, Ljubljana.

GURS (2006): Digitalni model višin (DMV 0125). Rastrska vrsta podatka v ESRI GRID formatu. - Geodetska uprava RS, Ljubljana.

GURS (2009): Register nepremičnin (REN): REN_stavbe. Tekstovna vrsta podatka v ASCII formatu. - Geodetska uprava RS, Ljubljana.

Hanžel, J., Alhady, O., Kozina, A. \& Repotočnik, Ž. (20I I): Popis velikega skovika Otus scops in podhujke Caprimulgus europaeus v slovenski Istri leta 2010 in 2011. pp. In: Mladinski ornitološki raziskovalni tabor Rakitovec 2011. Poročila skupin. - DOPPS, Ljubljana.

Hardouin, L.A., Reby, D., Bavoux, C., Burneleau, G. \& Bretagnolle, V. (2007): Notes and Comments: Communication of male quality in owl hoots. - The American Naturalist 169 (4): 552-562.

Hein, S., Voss, J., Poethke, H.J. \& Schröder, B. (2007): Habitat suitability models for the conservation of thermophilic grasshoppers and bush crickets - simple or complex? - Journal of Insect Conservation 11: 221-240.

Heller, K.G. \& Arlettaz, R. (I994): Is there a sex ratio bias in the bushcricket prey of the Scops Owl due to predation on calling males? - Journal of Orthoptera research 2: 41-42.

Huntley, B., Green, R.E., Collingham, Y.C. \& Willis, S.G. (2007): A Climatic Atlas of European Breeding Birds. - Durham University, The RSPB \& Lynx Edicions, Barcelona.

Hutтo, R. (1985): Habitat selection by nonbreeding, migratory land birds. pp. 455-476 In: Cody, M.L. (ed.): Habitat selection in birds. - Academic Press Inc., Orlando, Florida.

Keller, E. \& Parrag, M. (I996): [The Scops Owl Otus scops (L.) in Mattersburg/Burgenland: the biology and ecology of the Scops Owl and the importance of grassland areas with scattered old fruit trees as a habitat.] - Bericht über das Zwergohreulenschutzprojekt 1995. Burgenländische Landesregierung (Abt. IV Naturschutz). (in German)

Kmecl, P. \& Š Etina, T. (2007): Popis velikega skovika Otus scops na Krasu v letu 2006. Zaključno poročilo Interreg IIIA Slovenija-Italija 2000-2006. - DOPPS, Ljubljana.

Koce, U. (2007): Poročilo o delu skupine za kobilice, RTŠB Dekani 2004. pp. 44-49 In: Polajnar, J. (ed.): Raziskovalni tabor študentov biologije Lovrenc na Pohorju 2005. - Društvo študentov biologije, Ljubljana.

KöHLER, G. (I 996): The ecological background of population vulnerability in central European grasshoppers and bush crickets: a brief review. pp. 290-298 In: Settele, J., Margueles, C., Poschlod, P. \& Henle, K. (eds.): Species Survival in Fragmented Landscapes. - Kluwer Academic Publishers, Dordrecht.

KRIŠTín, A. \& KaŇUCH, P. (2009): [Survival strategies in endangered vertebrate species and their conservation.] pp. 8-9 In: Správa o činnosti organizácie SAV za rok 2008. - Institutum Oecologiae, Slovenská Akadémia Vied, Ústav ekológie lesa, Zvolen. (in Slovak)

LipeJ, L. (2000): Prispevek k poznavanju ptic vinogradov slovenske Istre. - Kozarec sonca 22: 313-322.

Lipej, L., Sovinc, A. \& Lipej, B. (2005): Ujede in sove na robu Sredozemlja. pp. 59-60, 119-120 \& 154-155 In: Laguna, E., Deltoro, V., Lipej, B., Kaligarič, M., Sovinc, A. (eds.): Pestrost in ohranjanje kraške pokrajine: primeri iz Valencije in Slovenije. - Univerza na Primorskem, Znanstveno-raziskovalno središče, Koper.

Malus, M. (2007): Gospodarsko pomembne vrste metuljev (Lepidoptera) v vinogradniški favni v okolici Trške gore. Diplomsko delo. - Univerza v Ljubljani, Biotehniška fakulteta, Oddelek za agronomijo, Ljubljana.

Manly, B.F., McDonald, L.L., Thomas, D.L., McDonald, T.L. \& Erickson, W.P. (2002): Resource Selection by Animals. Statistical Design and Analysis for Field Studies. - Kluwer Academic Publishers, Dordrecht.

Marchesi, L. \& Sergio F. (2005): Distribution, density, diet and productivity of the Scops Owl Otus scops in the Italian Alps. - Ibis 147: 176-187.

Martinez, J.A., Zuberogoitia, I., Martinez, J.E., Zabala, J. \& Calvo, J.F. (2007): Patterns of territory settlement by Eurasian scops-owls (Otus scops) in altered semi-arid landscapes. - Journal of Arid Environments 69: 400-409.

MKGP (2007): Vektorska karta dejanske rabe kmetijskih in gozdnih zemljišč. Vektorska vrsta podatka v SHP formatu. - Ministrstvo za kmetijstvo, gozdarstvo in prehrano, Ljubljana.

MuraOKa, Y. (2009): [Video analysis of the Scops Owl in Carinthia: Analysis of infrared photos of a nestbox: breeding season 2007.] - Naturschutz, Wien. (in German)

Mužinič, J. \& Purger, J.J. (2008): Scops Owl Otus scops. Acrocephalus 29 (136): 73-75.

NAGELKerKe, N.J.D. (I99I): A note on a general definition of the coefficient of determination. - Biometrika 78 (3): 691-692.

Neu, C.W., Byers, C.R. \& Peek, J.M. (I974): A technique for analysis of utilization-availability data. - Journal of Wildlife Management 38: 541-545.

Ogrin, D. (2004): Modern climate change in Slovenia. pp: 45-50 In: OrožEn Adamič, M. (ed.): Slovenia: a geographical overview. - Založba ZRC, Ljubljana.

Pavelčín, P. (2000): [First breeding record of the European Scops Owl (Otus scops) in the Czech Republic, history and present of occurrence in the Moravia.] - Buteo 11: 149-156. (in Czech)

Polak, S. (ed.) (200o): Mednarodno pomembna območja za ptice $v$ Sloveniji. Important Bird Areas (IBA) in Slovenia. Monografija DOPPS št. 1. - DOPPS - BirdLife Slovenia, Ljubljana. 
T. ŠušmeLJ: The impact of environmental factors on distribution of Scops Owl Otus scops in the wider area of Kras (SW Slovenia)

Reijnen, R., Foppen, R. \& Meeuwsen, H. (I996): The effects of car traffic on the density of breeding birds in Dutch Agricultural Grasslands. - Biological Conservation 75: 255-260.

Rubinič, B., BožIČ, L., Denac, D. \& Mihelič, T. (2004): Monitoring populacij izbranih vrst ptic. Rezultati popisov v sezoni 2004. Drugo vmesno poročilo. Naročnik: Ministrstvo za okolje, prostor in energijo. DOPPS, Ljubljana.

Rubinič, B. (2005): Monitoring populacij izbranih vrst ptic. Končno poročilo. Naročnik: Ministrstvo za okolje in prostor. - DOPPS, Ljubljana.

Rubinič, B., Mihelič, T., Božıč, L., Denac, D. \& KMecl, P. (2006): Monitoring populacij izbranih vrst ptic. Rezultati popisov v gnezditveni sezoni 2006. Vmesno poročilo. Naročnik: Ministrstvo za okolje in prostor. DOPPS, Ljubljana.

Rubinič, B., Božič, L., Denac, D. \& KMecl, P. (2007): Poročilo monitoringa izbranih vrst ptic na posebnih območjih varstva (SPA). Rezultati popisov v gnezditveni sezoni 2007. Končno poročilo. Naročnik: Ministrstvo za okolje in prostor. - DOPPS, Ljubljana.

Rubinič, B., Božič, L., Kmecl, P., Denac, D. \& Denac, K. (2008): Monitoring populacij izbranih vrst ptic. Rezultati popisov v spomladanski sezoni 2008. Vmesno poročilo. Naročnik: Ministrstvo za okolje in prostor. DOPPS, Ljubljana.

Rubinič, B., Božıč, L., Denac, D., Mihelič, T. \& KMecl, P. (2009): Monitoring populacij izbranih vrst ptic. Rezultati popisov v spomladanski sezoni 2009. Naročnik: Ministrstvo za okolje in prostor. - DOPPS, Ljubljana.

Sacchi, R., Perani, E. \& Galeotti, P. (i999): Population density and demographic trend of the Scops Owl Otus scops in the Northern Apennine (Oltrepo Pavese, Northern Italy). - Avocetta 23 (2): 58-64.

Samwald, O. \& SAmwald, F. (I992): Brutverbreitung und Bestandsentwicklung der Zwergohreule (Otus scops) in der Steiermark. - Egretta 35 (1): 37-48.

SenegaČnik, K. (I998): Popis velikega skovika Otus scops na Ljubljanskem barju. - Acrocephalus 19 (90/91): $143-146$.

Seoane, J., Bustamante, J. \& Diaz-Delgado, R. (2004): Competing roles for landscape, vegetation, topography and climate in predictive models of bird distribution. Ecological Modelling 171 (3): 209-222.

Sergio, F. \& Newton, I. (2003): Occupancy as a measure of territory quality. - Journal of Animal Ecology 72 (5): $857-865$.

Sergio, F., Marchesi, L. \& Pedrini, P. (2009): Conservation of Scops Owl Otus scops in the Alps: relationships with grassland management, predation risk and wider biodiversity. - Ibis 151 (1): 40-50.

SPSS (2008): SPSS for Windows, ver. 17.0. - SPSS Inc., Chicago IL.

Streit, B. \& Kalotás, Z. (I99I): The reproductive performance of the Scops Owl (Otus scops L., 1758). Aquila 98: 97-105.

Šotnár, K., Krištín, A., SÁrossy, M. \& Harvančík, S. (2008): [On foraging ecology of the Scops Owl (Otus scops) at the northern limit of its area.] - Tichodroma 20: 1-6. (in Slovak)
Štumberger, B. (2000): Veliki skovik Otus scops na Goričkem. - Acrocephalus 21 (98/99): 23-26.

ŠušmeLJ, T. (2012): Razširjenost in izbor habitata velikega skovika (Otus scops) na širšem območju Krasa. Magistrsko delo. - Univerza v Ljubljani, Biotehniška fakulteta, Ljubljana.

TARMAn, K. (I 992): Osnove ekologije in ekologije živali. DZS, Ljubljana.

TrontelJ, P. (200o): Kras. pp. 51-64 In: PolaK, S. (ed.): Mednarodno pomembna območja za ptice v Sloveniji. Important Bird Areas (IBA) in Slovenia. Monografija DOPPS št. 1. - DOPPS - BirdLife Slovenia, Ljubljana.

UrAdni LIST RS (2002): Pravilnik o uvrstitvi ogroženih rastlinskih in živalskih vrst v rdeči seznam. (no. 82/02).

URADNI LIST RS (2004A): Uredba o zavarovanih prosto živečih živalskih vrstah. (no. 46/04).

URADNI LIST RS (2004B): Uredba o ekološko pomembnih območjih. (no. 48/04).

URADNI LIST RS (2004c): Uredba o posebnih varstvenih območjih (območjih Natura 2000). (no. 49/04).

VRezec, A. (200I): The breeding density of Eurasian Scops Owl Otus scops in urban areas of Pelješac peninsula in southern Dalmatia. - Acrocephalus 22 (108): 149-154.

Vrezec, A. \& Tome, D. (2004): Habitat selection and patterns of distribution in a hierarchic forest owl guild. Ornis Fennica 81: 109-118.

Worton, B.J. (1989): Kernel methods for estimating the utilization distribution in home range studies. - Ecology 70 (1): 164-168.

ZelNiK, D. (ed.) (2008): Ohranitev kraške krajine kot razvojna priložnost Krasa. Zbornik referatov in razprav. - Državni svet Republike Slovenije, Ljubljana.

Arrived / Prispelo: 17. 12. 2009

Accepted / Sprejeto: 19. 3. 2012 